\title{
Effectiveness of Contaminants Removal in the Summer and Winter Season in a Small Sewage Treatment Plant Operating Based on the Trickling Biofilters Technology
}

\author{
Kamil Łukasz Bryszewski i*, Joanna Rodziewicz', Artur Mielcarek1, \\ Wojciech Janczukowicz ${ }^{1}$ \\ 1 University of Warmia and Mazury in Olsztyn, Department of Environment Engineering, Warszawska St. 117a, \\ Olsztyn 10-719, Poland \\ * Corresponding author's e-mail: kamil.bryszewski@uwm.edu.pl
}

\begin{abstract}
This study aimed to evaluate the operation technology and functioning of the facilities for the treatment of municipal sewage in a small wastewater treatment plant operating based on the trickling biofilters technology, in the winter (February) and summer (June-July) periods. Additional analyses were conducted to determine the effectiveness of contaminants removal in particular facilities of the technological system tested. The study results indicate that the sewage treatment plant operating based on the trickling biofilters technology ensures effective removal of organic compounds, total nitrogen, total phosphorus, and total suspended solids. In the summer period, the effectiveness of contaminants removal reached $92 \%, 52.9 \%, 97.9 \%$, and $99.9 \%$, respectively, whereas in the winter season, it was lower an reached $69.5 \%, 12.4,93.0$, and $95.0 \%$, respectively. The treatment effectiveness achieved in this study was referred to the results of the investigations conducted in the same sewage treatment plant 24 years ago. The results obtained may provide a valuable guideline to designers and operators of small sewage treatment plants.
\end{abstract}

Keywords: trickling biofilters, denitrification, small sewage treatment plant

\section{INTRODUCTION}

Municipal sewage treatment plants usually operate based on the processes enabling the removal of suspended solids, organic compounds, and biogenes (phosphorus and nitrogen). Discharge of insufficiently treated wastewater to the natural environment may have an adverse effect on the receiver. Despite establishment of new and modernization of the existing wastewater treatment plants, the condition of waters in Poland is still unsatisfactory and the problem of their eutrophication remains unresolved [Makowska 2015, Neverowa Dziobak and Preisner 2016].

The treatment of sewage from individual households or their small groups in rural areas which are remote from a sewage system poses a serious problem [Chmielowski et al. 2011]. One of the methods for sewage management on these areas involves the use of septic tanks
[Krzanowski et al. 2005] . According to the data provided in reports of the Main Statistical Office (GUS), over 2,000,000 septic tanks were in use in Poland in 2017 [Adamczyk et al. 2018]. It needs to be emphasized that objects of this type are often leaky, which poses a threat to the surface and underground waters. Septic tanks should be regularly emptied, which entails high costs [Pryszcz and Mrowiec 2015]. Such a solution is justified when the building plot is going to be connected to a collective sewage system. Another solution to the problem of sewage management in rural areas, where there are no plans for building a complex treatment system, is the use of small sewage treatment plants (including the household ones). The most common solutions in this case include: hydrophyte treatment plants, treatment plants with a biofilter, and treatment plants with activated sludge. In 2015, there were only 27,900 household treatment plants in 
Poland, whereas in 2017, their number increased to 233,800 [Adamczyk et al. 2018].

In Poland, no legal consent is required when discharging up to $5 \mathrm{~m}^{3} \cdot \mathrm{L}^{-1}$ of sewage into the environment within the owner's plot. The consent is required if the volume of sewage exceeds $5 \mathrm{~m}^{3} \cdot \mathrm{L}^{-1}$ or if the sewage is planned to be discharged outside the owner's plot (regardless of volume).

The information provided in reports of the Main Statistical Office indicates a continuous increase in the number of household treatment plants and small sewage treatment plants. In addition, the growing awareness of residents of rural areas about the need for sewage treatment allows concluding that the number of such facilities will continue to grow. However, it should be borne in mind that these objects are not under continuous technological control and the sewage discharged from the treatment plants may not meet requirements with regard to their quality. In addition, there are insufficient reports in the literature on the functioning of objects of this type. Hence the need emerges for more research on the functioning and effectiveness of small sewage treatment plants.

This study aimed to evaluate the operation technology and functioning of a small sewage treatment plant based on the trickling biofilters technology in the winter period (February) and in the summer period (June-July). Additional analyses were conducted to determine the effectiveness of contaminants removal in particular facilities of the technological system of the tested plant. The results obtained may provide a valuable guideline to designers and operators of small sewage treatment plants.

\section{METHODS}

The subject of the study included household sewage subjected to the treatment process in the north-eastern Poland. The sewage treatment plant under study is located in the Warmia and Mazury Province and its task is to treat the sewage from a Social Welfare Home and from individual households in its vicinity. The population equivalent (PE) for this treatment plant is $250 \mathrm{PE}$, and the plant receives $60 \mathrm{~m}^{3}$ of sewage/day, on average.

The technological system of the sewage treatment plant (Fig. 1) includes the following facilities:

- three-chamber septic tank,

- preliminary sedimentation tank,

- 'BIOCLERE' sewage system plant which includes:

- biofilter,

- nitrification filter,

- unit for chemical precipitation of phosphorus,

- secondary settlement tank.

The sewage from the Social Welfare Home first reaches the 3-chamber septic tank with the volume of $75 \mathrm{~m}^{3}$, wherein mineral suspensions, easily-falling suspensions, and floating substances are retained. Next, the gravitational sewage flows to a preliminary sedimentation tank built of two chambers made of reinforced concrete with the total volume of $22 \mathrm{~m}^{3}$. The preliminary sedimentation tank also receives sewage from individual households. Next, the sewage flows from the preliminary tank to the bio-chemical unit of the 'BIOCLERE' sewage treatment plant. The plant operates based on a 3-stage sewage treatment process:



Figure 1. Scheme of sewage treatment plant (1 - inflow of crude sewage from Social Welfare Home, 2 -3-chamber septic tank, 3 - crude sewage from households, 4 - preliminary sedimentation tank

I, 5 - preliminary sedimentation tank II, 6 - biofilter, 7 - nitrification filter, 8 - unit for chemical precipitation of phosphorus-secondary settlement tank, 9 - outflow of treated sewage, 10 - sludge recirculation) 
- I stage - type B 180 biofilter exploiting the basic process of biochemical degradation of organic contaminants. The filter is filled with HUFO 120 pipe fittings with a total volume of $21.6 \mathrm{~m}^{3}$. A sludge chamber is fixed inside the sedimentation tank. The sewage is pumped from the sludge chamber to the first chamber of the preliminary sedimentation tank.

- II stage - type B115 biofilter, filled also with HUFO 120 pipe fittings with a total volume of $13.8 \mathrm{~m}^{3}$. The II stage enables a continued removal of organic contaminants and nitrification. A tank made of reinforced concrete is fixed under the filter, which contains a sludge chamber with the volume of $4.8 \mathrm{~m}^{3}$.

- III stage - a chemical unit for precipitation of phosphorus compounds. Phosphorus is precipitated with a solution of PIX coagulant. A secondary settlement tank made of reinforced concrete is fixed under the chamber of the chemical unit. It collects the sludge from the biological and chemical treatment process. The effluent is discharged from the secondary settlement tank to a receiver.

The sludge retained in tanks of the biological and chemical unit is removed to the preliminary sedimentation tank.

The sewage samples were collected in the winter period (February 2018) and in the summer period (June 2018) once the sewage passed through each facility of the technological system. The analyses performed allowed determining the effectiveness of the entire treatment system.

The samples of sewage were collected 4 times ( 2 times in the winter period and 2 times in the summer period). After filtration, they were analyzed for:

- concentration of organic compounds expressed in COD value - using a UV-VIS 5000 DR spectrophotometer (HACH Lange, Germany), with the HACH Lange LCK 414,514,614 method;

- concentration of total phosphorus - using a UV-VIS 5000 DR spectrophotometer (HACH Lange, Germany), with the HACH Lange LCK 348-350 method;

- concentration of total nitrogen - with the 'oxidative incineration - chemiluminescence' method using a TNM-L analyzer (Shimadzu Corporation, Japan);

- concentration of ammonia nitrogen and nitrate(III) nitrogen - with the colorimetric method;
- concentration of nitrate(V) nitrogen - using a UV-VIS 5000 DR spectrophotometer (HACH Lange, Germany), with the HACH Lange LCK 339-340 method;

- $\mathrm{pH}$ value - with a CX-461 pH-meter (Elmetron, Poland);

- concentration of total suspended solids with the gravimetric method (acc. to PN-EN 872:2007).

\section{RESULTS AND DISCUSSION}

The subject of the study was the effluent from a small sewage treatment plant with PE 250. The plant collects on average $60 \mathrm{~m}^{3}$ sewage/day from individual households and from a Social Welfare Home (90 residents). The results of the analyses conducted in the study were presented in Table 1 and in Figures 2 and 3.

One of the key factors which affect the rate of biological processes in a biofilm is temperature; this applies to the nitrification process, which is largely dependent on the thermal conditions [Hwang and Oleszkiewicz 2007]. The analysis of the data presented in Table 1 allows concluding that the highest volume of organic compounds, expressed with a COD index, was removed via sedimentation, flotation, and degradation under anaerobic conditions in the septic tank, regardless of the season. The effectiveness of the organic compounds removal reached $56.8 \%$ in the winter season and $52.3 \%$ in the summer season. In turn, the percentage of organic compounds removal on biofilms reached $2.4 \%$ and $34.1 \%$ in respective seasons. In turn, the coagulation process enabled reducing the organic compounds load by 17.5 in winter and by $74.4 \mathrm{mg} \mathrm{O}{ }_{2} \mathrm{~L}^{-1}$ in summer. According to the study conducted by Kopeć and Świsłowski [2009] for the Bioclere type wastewater treatment plants, the treatment of wastewater is effective when the loading of trickled biofilters with organic compounds (expressed per $\mathrm{BOD}_{5}$ ) does not exceed $0.100 \mathrm{~kg}$ $\mathrm{O}_{2} \cdot \mathrm{L}^{-1} \cdot \mathrm{d}^{-1}$. This load of organic compounds ensures also effective nitrification [Kopeć and Świsłowski 2009]. In the case of the studied treatment plant, the load of organic compounds expressed per $\mathrm{BOD}_{5}$ reached $0.409 \mathrm{~kg} \mathrm{O} \mathrm{O}_{2} \mathrm{~L}^{-1}$ $\cdot \mathrm{d}^{-1}$ (biofilm) and $0.619 \mathrm{~kg} \mathrm{O} \cdot \mathrm{L}^{-1} \cdot \mathrm{d}^{-1}$ (nitrifying film) in the winter period as well as $1.183 \mathrm{~kg}$ $\mathrm{O}_{2} \cdot \mathrm{L}^{-1} \cdot \mathrm{d}^{-1}$ and $0.913 \mathrm{~kg} \mathrm{O}_{2} \cdot \mathrm{L}^{-1} \cdot \mathrm{d}^{-1}$, respectively, in the summer period. 
Table 1. Characteristics of sewage outflowing from particular facilities of the technological system of the small sewage treatment plant tested

\begin{tabular}{|c|c|c|c|c|c|c|c|c|c|c|c|c|c|c|c|c|}
\hline \multirow{2}{*}{$\begin{array}{l}\text { Indicators } \\
\text { Research } \\
\text { period } \\
\text { Device }\end{array}$} & & \multicolumn{2}{|c|}{$\begin{array}{c}\text { Organic } \\
\text { compounds } \\
-(\mathrm{COD}) \\
{\left[\mathrm{mg} \mathrm{O}_{2} \cdot \mathrm{L}^{-1}\right]}\end{array}$} & \multicolumn{2}{|c|}{$\begin{array}{c}\text { Total } \\
\text { phosphorus } \\
{\left[\mathrm{mg} \mathrm{P}^{\left.-L^{-1}\right]}\right.}\end{array}$} & \multicolumn{2}{|c|}{$\begin{array}{c}\text { Total } \\
\text { nitrogen } \\
{\left[\mathrm{mg} \mathrm{N} \cdot \mathrm{L}^{-1}\right]}\end{array}$} & \multicolumn{2}{|c|}{$\begin{array}{c}\text { Nitrate(III) } \\
\text { nitrogen } \\
{\left[\mathrm{mg} \mathrm{N}^{-1} \mathrm{~L}^{-1}\right]}\end{array}$} & \multicolumn{2}{|c|}{$\begin{array}{l}\text { Ammonia } \\
\text { nitrogen } \\
\left.\mathrm{mg} \mathrm{N} \cdot \mathrm{L}^{-1}\right]\end{array}$} & \multicolumn{2}{|c|}{$\begin{array}{l}\text { Nitrate(V) } \\
\text { nitrogen } \\
{\left[\mathrm{mg} \mathrm{N} \cdot \mathrm{L}^{-1}\right]}\end{array}$} & \multicolumn{2}{|c|}{$\begin{array}{c}\text { Total } \\
\text { suspended } \\
\text { solids }\left[\mathrm{mg} \cdot \mathrm{L}^{-1} \text { ] }\right.\end{array}$} \\
\hline & 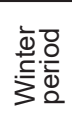 & 象 & 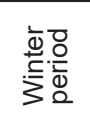 & 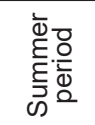 & 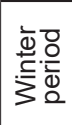 & 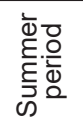 & : & 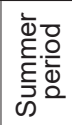 & & 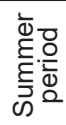 & 㐫。 & & 㐫 & & $\begin{array}{l}\stackrel{\Phi}{\Phi} \\
. \subseteq\end{array}$ & 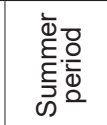 \\
\hline intistonl & & 4 & $3 \stackrel{ \pm}{3} .2$ & & $\pi$ & 1. & & $\begin{array}{c}91.6 \\
\pm \\
4.8\end{array}$ & & & $\begin{array}{l} \pm \\
0.9\end{array}$ & $\begin{array}{c}63.4 \\
\pm \\
4.4\end{array}$ & & 0.8 & & \\
\hline & 02 & 36 & & & & $=$ & & $\begin{array}{c}66.7 \\
\pm \\
6.9\end{array}$ & & & $\begin{array}{c}68.7 \\
\pm \\
12.9 \\
\end{array}$ & $\begin{array}{c}45.8 \\
\pm \\
5.9\end{array}$ & & 0.3 & $3 / 0$. & 49.1 \\
\hline & $\begin{array}{l}33 \\
\pm \\
02\end{array}$ & $\begin{array}{l}70 \\
\pm \\
45\end{array}$ & $\begin{array}{l}20.5 \\
\pm \\
7.7\end{array}$ & & 3.2 & 1.7 & & $\begin{array}{c}60.1 \\
\pm \\
8.3\end{array}$ & & & $\begin{array}{c}60.8 \\
\pm \\
6.5\end{array}$ & 43.5 & $\begin{array}{l}.38 \\
\pm \\
.07\end{array}$ & 06 & $\begin{array}{c}161.4 \\
\pm\end{array}$ & 1461 \\
\hline ofilter & 20 & $\begin{array}{l}63 \\
\frac{1}{36}\end{array}$ & 0.5 & & . & 1 & & $\begin{array}{c}62.3 \\
\pm \\
5.4\end{array}$ & & & $\begin{array}{c}51.7 \\
\pm \\
5.1\end{array}$ & $\begin{array}{r}43.5 \\
+\end{array}$ & & $\begin{array}{l}0.8 \\
\pm \\
0.5\end{array}$ & $\begin{array}{r}162 \\
\pm \\
45\end{array}$ & $\begin{array}{l}45.0 \\
\pm \\
15.9\end{array}$ \\
\hline & $\begin{array}{l}18 \\
\pm \\
02\end{array}$ & $\begin{array}{l}85 \\
\pm \\
54\end{array}$ & 3.5 & 388. & $\underset{ \pm}{3.0}$ & $\begin{array}{c}1.4 \\
\pm\end{array}$ & $\begin{array}{c}63.5 \\
\pm\end{array}$ & $\begin{array}{c}55.8 \\
\pm \\
3.8\end{array}$ & & 07 & $\begin{array}{c}47.4 \\
\pm\end{array}$ & $\underset{ \pm}{38.0}$ & $\begin{array}{l}0.45 \\
\pm \\
0.17\end{array}$ & $\begin{array}{l}1.17 \\
\pm .99\end{array}$ & $\begin{array}{l}178.5 \\
111.6\end{array}$ & 8.0 \\
\hline $\begin{array}{l}\text { mical } \\
\text { cipitation }\end{array}$ & $\begin{array}{l}25 \\
\pm \\
04\end{array}$ & $\begin{array}{l}82 \\
\pm \\
40\end{array}$ & $\begin{array}{l}38.0 \\
\pm \\
6.6\end{array}$ & $\begin{array}{c}154.5 \\
\pm \pm .7 \\
34.7\end{array}$ & 2.4 & $\begin{array}{c}0.9 \\
\pm \\
0.03\end{array}$ & $\begin{array}{c}63.1 \\
\pm \\
2.0\end{array}$ & $\begin{array}{c}48.0 \\
\pm \\
1.3\end{array}$ & 1 & $\begin{array}{l}.15 \\
\pm .14 \\
.14\end{array}$ & $\begin{array}{c}53.3 \\
\pm \\
6.0\end{array}$ & $\begin{array}{c}30.1 \\
\pm \\
7.9\end{array}$ & $\begin{array}{l}.49 \\
\pm \\
.83\end{array}$ & $\begin{array}{l}1.42 \\
\pm \pm \\
1.47\end{array}$ & $\begin{array}{c}284.8 \\
12.3\end{array}$ & $\begin{array}{l}37.6 \\
\pm \pm \\
19.0\end{array}$ \\
\hline & $\begin{array}{l}16 \\
\pm \\
01\end{array}$ & $\begin{array}{l}8.04 \\
\pm \\
0.26\end{array}$ & $\begin{array}{l}60.5 \\
1 \pm .9\end{array}$ & $\begin{array}{l}80.1 \\
\pm \pm \\
16.0\end{array}$ & $\begin{array}{l}0.4 \\
\pm \\
0.6\end{array}$ & $\begin{array}{c}0.2 \\
\pm \\
0.05\end{array}$ & $\begin{array}{c}62.6 \\
\pm \\
3.6\end{array}$ & $\begin{array}{c}43.1 \\
\pm \\
2.3\end{array}$ & & 0.17 & $\begin{array}{c}47.0 \\
\pm \\
4.6\end{array}$ & $\begin{array}{c}25.1 \\
\pm \\
2.3\end{array}$ & $\begin{array}{l}0.80 \\
\pm \\
0.30\end{array}$ & 20.97 & $\begin{array}{c}76.8 \\
\pm \\
3.3\end{array}$ & $\stackrel{ \pm}{ \pm .5}$ \\
\hline
\end{tabular}

The concentration of total nitrogen in sewage in the septic tank reached $72.6 \pm 14.8 \mathrm{mg} \mathrm{N} \cdot \mathrm{L}^{-1}$ and $91.6 \pm 4.8 \mathrm{mg} \mathrm{N} \cdot \mathrm{L}^{-1}$ in the winter and summer seasons, respectively. In the preliminary sedimentation tank, the $\mathrm{N}$ concentration increased to $80.0 \pm 15.5 \mathrm{mg} \mathrm{N} \cdot \mathrm{L}^{-1}$ in the winter. It is noteworthy that this tank also collects the sewage from individual households, which could cause an increase in the nitrogen concentration in the sewage. In the winter period, the nitrogen compounds were removed mainly on biofilms wherein denitrification reached $5.9 \%$ of total nitrogen. In the summer period, total nitrogen removal in the septic tank accounted for $51.3 \%$, and this tank turned out to be the facility which ensured the highest nitrogen removal. The use of biofilters in the treatment process in the summer period allowed an additional removal of $29.7 \%$ of total nitrogen in the denitrification process.

Depending on the sampling site, the $\mathrm{pH}$ value of sewage ranged from 7.7 to 8.3 in the winter, and from 7.5 to 8 in the summer. The sewage $\mathrm{pH}$ in the range from 6.5 to 8 makes ammonia occur in the ionized form $-\mathrm{NH}_{4}^{+}$[Ignatowicz and $\mathrm{Pu}-$ chlik 2011].

Under anaerobic conditions, the organic nitrogen of sewage is subject to ammonification in the septic tank. The data from Table 1 demonstrate

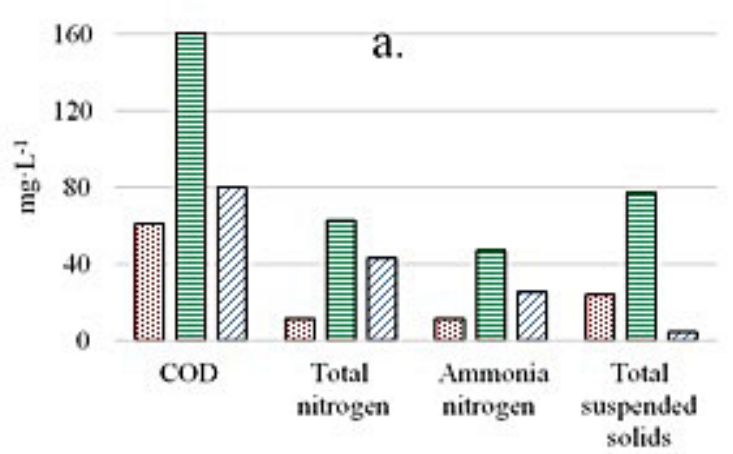

๑Pesta 1995 घWinter period ESummer period

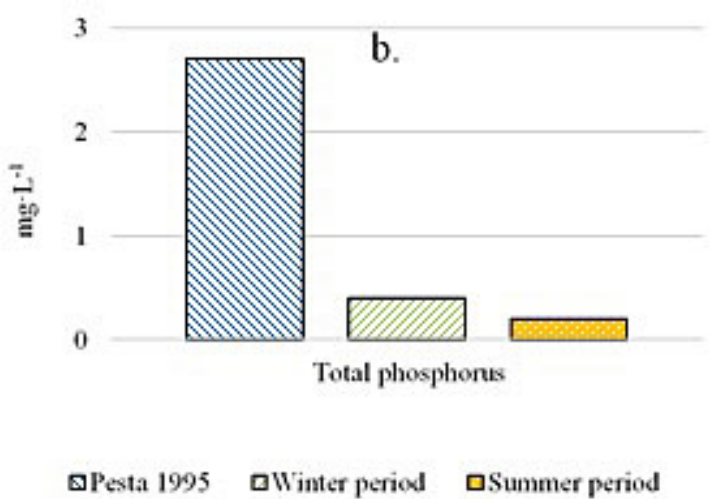

Figure 2. Concentration of organic compounds, total nitrogen, ammonia nitrogen, total suspended solids (a), and total phosphorus (b) in the effluent (Pesta 1995) 


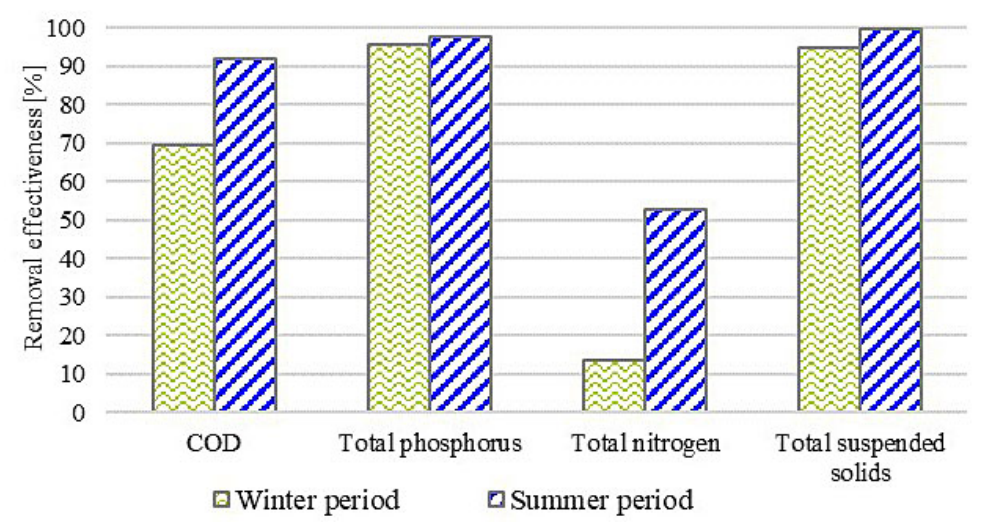

Figure 3. Effectiveness of contaminants removal in the study period

that, regardless of the sewage sampling site, the concentration of ammonia nitrogen determined in the winter period was high and achieved the maximum value of $68.7 \pm 12.9 \mathrm{mg} \mathrm{N} \cdot \mathrm{L}^{-1}$ (preliminary sedimentation tank). The lowest concentration of ammonia nitrogen $\left(47.0 \pm 4.6 \mathrm{mg} \mathrm{N} \cdot \mathrm{L}^{-1}\right)$ was determined at the end of the technological system in the effluent. In the summer period, the concentration of ammonia nitrogen in the sewage outflowing from the septic tank reached $63.4 \pm 4.4 \mathrm{mg} \mathrm{N} \cdot \mathrm{L}^{-1}$, whereas in the effluent outflowing from the treatment plant, it reached $25.1 \pm 2.3 \mathrm{mg} \mathrm{N} \cdot \mathrm{L}^{-1}$. The higher concentrations of ammonia nitrogen noted in the winter period could be due to low temperatures which lowered the rate of biochemical processes [Krzanowski et al. 2005]. In the winter period, the load of ammonia nitrogen in filters of the treatment plant tested accounted for $0.143 \mathrm{~kg} \mathrm{~N}-\mathrm{NH}_{4} \cdot \mathrm{L}^{-1} \cdot \mathrm{d}^{-1}$ in the biofilter and for $0.206 \mathrm{~kg} \mathrm{~N}-\mathrm{NH}_{4} \cdot \mathrm{L}^{-1} \cdot \mathrm{d}^{-1}$ in the nitrifying filter. In the summer period, the respective values were at $0.121 \mathrm{~kg} \mathrm{~N}-\mathrm{NH}_{4} \cdot \mathrm{L}^{-1} \cdot \mathrm{d}^{-1}$ and $0.165 \mathrm{~kg} \mathrm{~N}-\mathrm{NH}_{4} \cdot \mathrm{L}^{-1} \cdot \mathrm{d}^{-1}$. In the study conducted by Kopeć and Śsisłowski [2009] with Bioclere trickling biofilters, the effectiveness of nitrification increased along with a decreasing filter loading with ammonia nitrogen. At the loading of $0.0684 \mathrm{~kg} \mathrm{~N}-\mathrm{NH}_{4} \cdot \mathrm{L}^{-1} \cdot \mathrm{d}^{-1}$, the nitrification effectiveness accounted for $57.1 \%$, whereas at the loading of $0.0259 \mathrm{~kg} \mathrm{~N}-\mathrm{NH}_{4} \cdot \mathrm{L}^{-1} \cdot \mathrm{d}^{-1}$ it increased to 85.7\% [Kopeć and Świsłowski 2009].

The concentration of total phosphorus in sewage in the septic tank was at $8.3 \pm 1.4 \mathrm{mg} \mathrm{P} \cdot \mathrm{L}^{-1}$ and $8.3 \pm 1.6 \mathrm{mg} \mathrm{P} \cdot \mathrm{L}^{-1}$ in the winter and summer, respectively. Regardless of the season, the highest effectiveness of phosphorus compounds removal was achieved in the preliminary sedimentation tank and reached $44.2 \%$ in winter and $81.4 \%$ in summer. The design of the technological system assumed sludge recirculation from the secondary settling tank to the preliminary sedimentation tank after the chemical stage of treatment. The non-reacted coagulant probably ensured a high effectiveness of phosphorus removal already in the preliminary sedimentation tank. It needs to be emphasized that the main technological facility responsible for the phosphorus removal turned out to be the chemical unit for phosphorus precipitation. Because of the adopted technological solutions, the sewage flowing into the chemical precipitation unit was already characterized by a low concentration of phosphorus compared to crude sewage. The concentration of phosphorus in the sewage flowing into the chemical precipitation unit reached $2.4 \pm 3.5 \mathrm{mg} \mathrm{P} \cdot \mathrm{L}^{-1}$ in the winter period and $1.0 \pm 0.03 \mathrm{mg} \mathrm{P} \cdot \mathrm{L}^{-1}$ in the summer period. The low concentration of phosphorus in the sewage flowing into the coagulation unit resulted in a low effectiveness of phosphorus removal in this facility, which accounted for $25.4 \%$ and $9.6 \%$ in winter and summer, respectively.

The qualitative analysis of the crude sewage collected by the treatment plant under study was also conducted 24 years earlier by Pesta [1995]. In that period, the crude sewage was characterized by the following mean values of contamination indicators: COD $413.9 \mathrm{mg}$ $\mathrm{O}_{2} \cdot \mathrm{L}^{-1}, \mathrm{BOD}_{5} 207.9 \mathrm{mg} \mathrm{O} \cdot \mathrm{L}^{-1}$, ammonia nitrogen $21.8 \mathrm{mg} \mathrm{N} \cdot \mathrm{L}^{-1}$, total nitrogen $31.9 \mathrm{mg} \mathrm{N} \cdot \mathrm{L}^{-1}$, and total phosphorus $5.8 \mathrm{mg} \mathrm{P} \cdot \mathrm{L}^{-1}$, and by the mean concentration of nitrate $(\mathrm{V})$ nitrogen in the range from 0.0 to $1.3 \mathrm{mg} \mathrm{N} \cdot \mathrm{L}^{-1}$. It needs to be emphasized that in the current study, the sewage flowing into the treatment plant (Table 1) was characterized by higher values of the above-mentioned indicators. The greatest differences could be noticed in total nitrogen concentration in the crude sewage which in the present study was significantly higher than 
in the cited work and reached $72.6 \pm 14.8 \mathrm{mg} \mathrm{N} \cdot \mathrm{L}^{-1}$ in the winter and $91.6 \pm 4.8 \mathrm{mg} \mathrm{N} \cdot \mathrm{L}^{-1}$ in the summer. The same applied to the concentration of ammonia nitrogen: $53.9 \pm 0.9 \mathrm{mg} \mathrm{N} \cdot \mathrm{L}^{-1}$ in the winter and $63.4 \pm 4.4 \mathrm{mg} \mathrm{N} \cdot \mathrm{L}^{-1}$ in the summer. The concentration of organic compounds in sewage was the same as in the year $1995(526.5 \pm 33.2 \mathrm{mg}$ $\left.\mathrm{O}_{2} \cdot \mathrm{L}^{-1}\right)$. In turn, in the summer, the COD of sewage was over 2 times higher than in 1995 and reached $1005.5 \pm 125.2 \mathrm{mg} \mathrm{O}_{2} \cdot \mathrm{L}^{-1}$. The concentration of phosphorus compounds in sewage from the present study (in both winter and summer) was by ca. $2.5 \mathrm{mg} \mathrm{P} \cdot \mathrm{L}^{-1}$ higher than in 1995 , whereas the nitrate $(\mathrm{V})$ nitrogen concentration in crude sewage was similar in both years compared [Pesta 1995].

Figure $2 \mathrm{a}$ and Figure $2 \mathrm{~b}$ present the results of a comparative analysis of the quality of sewage treated in the current study and in 1995. The quality of the effluent analyzed in the study conducted 24 years ago was far better than that of the effluent from the present study, except for total phosphorus [Pesta 1995].

Figure 3 presents the mean removal effectiveness of organic compounds expressed by COD, total phosphorus, total nitrogen, and total suspended solids. It demonstrates that the removal effectiveness was lower in the winter than in the summer period. The greatest decline in the removal effectiveness was noted in the case of total nitrogen and organic compounds; it was higher by $39 \%$ and $22.5 \%$, respectively, in the summer than in the winter. In the case of total phosphorus and total suspended solids, their removal effectiveness in the summer period was only negligibly higher than in the winter, and the difference accounted for $2.4 \%$ and $4.9 \%$, respectively. In the same treatment plant, Pesta [1995] achieved the following effectiveness of contaminants removal 24 years earlier: COD $81.6 \%$, total nitrogen $46.9 \%$, and total phosphorus $53.7 \%$. The mean concentration of total phosphorus in crude sewage in the cited study was at $5.8 \mathrm{mg} \mathrm{P} \cdot \mathrm{L}^{-1}$, whereas in the present study, it reached ca. $8.3 \mathrm{mg} \mathrm{P} \cdot \mathrm{L}^{-1}$. However, it is noteworthy that the current effectiveness of total phosphorus removal was ca. $40 \%$ higher than that determined by Pesta [1995]. Bugajski and Kaczor [2008] conducted a comparative analysis of the removal effectiveness of 3 household sewage treatment plants in the summer and winter periods [Bugajski and Kaczor 2008]. The comparison concerned the following types of treatment plants: Turbojet EP-2 operating based on activated sludge, Turbojet Ep-4 operating mainly based on the primary sedimentation task and a bioreactor, and Bocompact BCT S-12 functioning based on low-loaded activated sludge. In that study, the effectiveness of contaminants removal in each of the 3 types of plants was higher in summer than in winter. The mean removal effectiveness of organic contaminants expressed by COD was $6.1 \%$ to $21.8 \%$ lower in the winter than in the summer period, that of total nitrogen was lower by 19.3 to $26.6 \%$, and that of total phosphorus by 11.9 to 27.2\% [Bugajski and Kaczor 2008]. In turn, in their research on horizontal-flow hydrophyte filters used for the treatment of synthetic municipal sewage Akratos and Tsihrintiz [2007] observed that temperature had a weak effect on the effectiveness of removal of organic compounds expressed by COD. At temperatures above $15^{\circ} \mathrm{C}$, the effectiveness reached $90.8 \%$, whereas at temperatures below $15^{\circ} \mathrm{C}$, it was significantly lower and reached ca. $87 \%$. In turn, in the case of total nitrogen and total phosphorus, the temperature had a significantly stronger effect on their removal effectiveness. At temperatures below $15^{\circ} \mathrm{C}$, the effectiveness of nitrogen compounds removal accounted for $58.5 \%$, whereas at temperatures above $15^{\circ} \mathrm{C}$ it was higher (73.9\%). In the case of total phosphorus, the respective values accounted for $41.8 \%$ and $70.1 \%$, respectively. These differences were mainly due to various activities of plants and microorganisms colonizing the hydrophyte filter [Akratos and Tsihrintiz 2007]. In the objects of this type, phosphorus removal is based, most of all, on the processes of adsorption and precipitation. The range of the above-mentioned temperatures was selected for the study because the processes of nitrogen compounds removal by plants and bacteria slow down at temperatures below $15^{\circ} \mathrm{C}$ [Kuschk et al. 2003, Vymazal 2004].

\section{CONCLUSIONS}

The results of the present study point to the effect of temperature on the removal effectiveness of contaminants from the sewage processed in a small sewage treatment plant operating based on trickling biofilters technology. The removal effectiveness determined for total nitrogen, organic compounds, total phosphorus, and total suspended solids was higher in the summer period. The greatest differences were noted for total nitrogen and organic compounds. After 24 years of exploitation, the analyzed treatment plant was 
characterized by similar effectiveness of contaminants removal to the values determined at the beginning of its functioning, whereas in the case of total phosphorus - the removal effectiveness was significantly higher today than 24 years ago.

Bearing in mind the simplicity of operation, low exploitation costs, and the demand for small treatment plants, the data presented in this work may provide a valuable guideline during the design and exploitation works at objects the functioning of which is based on the technological system with trickling biofilters and with the installation for chemical precipitation of phosphorus.

\section{Acknowledgements}

Publication is funded by the Polish National Agency for Academic Exchange under the International Academic Partnerships Programme from the project, Organization of the 9th International Scientific and Technical Conference entitled Environmental Engineering, Photogrammetry, Geoinformatics - Modern Technologies and Development Perspectives" and Project No. 29.610.023 of the University of Warmia and Mazury in Olsztyn, Poland.

\section{REFERENCES}

1. Adamczyk M., Różańska I., Sobczyk B. 2018. Municipal infrastructure in 2017 (in Polish). Główny Urząd Statystyczny, Warszawa, 2018.

2. Akratos V.A., Tsihrintzis C.S. 2007. Effect of temperature, HRT, vegetation and porous media on removal efficiency of pilot-scale horizontal subsurface flow constructed wetlands, Ecological Engineering, 29, 173-191.

3. Bugajski G., Kaczor P. 2008. Evaluation of operation of some domestic sewage treatment plants under winter and summer conditions (in Polish). Przemysł Chemiczny, 87, 424-426.

4. Chmielowski K., Slizowski K., Pegiel R. 2011. Evaluation of performance household sewage treatment plant based on a horizontal flow sand filter (in
Polish). Infrastruktura i Ekologia Terenów Wiejskich, 02, 215-223.

5. Hwang J.A., Oleszkiewicz J.H. 2007. Effect of Cold-Temperature Shock on Nitrification, Water Environment Research, 79, 964-968.

6. Ignatowicz M., Puchlik K. 2011. Rotary Biological Contactor as Alternative for Small Amount of Wastewater Treatment (in Polish). Rocznik Ochrona Środowiska, 13, 1385-1404.

7. Kopeć Ł., Świsłowski M. 2009. Influence of external recirculation on contaminants concentration in Bioclere treatment plant (in Polish). ŚrodkowoPomorskie Towarzystwo Naukowe Ochrony Środowiska, 11 1374-1380.

8. Kuschk U., Wiessner P., Kappelmeyer A., Weissbrodt U., Kästner E., Stottmeister M. 2003. Annual cycle of nitrogen removal by a pilot-scale subsurface horizontal flow in a constructed wetland under moderate climate. Water Research, 37, 4236-4242.

9. Krzanowski A., Walega S., Jucherski A. 2005. Influence of season on technological of reliability of multi-degrees plant-ground adjacent of sewage treatment (in Polish). Infrastruktura i Ekologia Terenów Wiejskich, 1, 37-55.

10. Makowska M. 2015. Nutrient removal in wastewater treatment plants SBR on non-urbanized areas in the context of the new reguirements ((in Polish). Gaz Woda i Technika Sanitarna, 1,15-19.

11. Neverova-Dziopak M., Preisner E. 2016. The impact of wastewater treatment technology on their eutrophication potential (in Polish). Journal of Civil Engineering, Environment and Architecture, 63, 295-313.

12. Pesta J. 1995. Removal of biogenic compounds in the BIOCLERE wastewater treatment plant (in Polish), in: Kontenerowe i Przydomowe Oczyszczlanie Ścieków Oraz Stacje Uzdatniania Wody, Fundacja Ekonomistów Środowiska i Zasobów Naturalnych, Wigry, 297-300.

13. Pryszcz B.M., Mrowiec M. 2015. Operation of the household sewage treatment plants in Poland. Inżynieria Ekologiczna, 41, 133-141.

14. Vymazal J. 2004. Removal of phosphorus in constructed wetlands with horizontal sub-surface flow in the Czech Republic. Water, Air, and Soil Pollution: Focus. 4, 657-670. 